\title{
Links between Autophagy, Innate Immunity, Inflammation and Crohn's Disease
}

\author{
Vojo Deretic \\ Department of Molecular Genetics and Microbiology, University of New Mexico School of Medicine, \\ Albuquerque, N. Mex., USA
}

\section{Key Words}

Autophagy $\cdot$ Innate immunity $\cdot$ Crohn's disease

\begin{abstract}
Autophagy is a fundamental biological process that endows eukaryotic cells with the ability to autodigest portions of their own cytoplasm. Autophagy plays roles in aging, development, neurodegeneration, cancer and immunity. The immunological role of autophagy was first recognized for the ability of autophagy to sanitize the cellular interior by killing intracellular microbes and, indirectly, by the adaptations that successful intracellular pathogens have evolved to protect themselves from autophagy. Since then, the repertoire of autophagy functions in immunity has been vastly expanded to include numerous intersections of regulatory and effector nature with innate and adaptive immunity. Autophagy acts both as an effector and a regulator of pattern recognition receptors, it supports MHC II presentation of cytosolic (self and microbial) antigens, it shapes central tolerance via thymic selection of the T cell repertoire, is an effector of Th1/Th2 polarization, affects homeostasis of T, B, and specialized immune cells such as Paneth cells, and - when defective - can be a contributing factor to chronic inflammatory conditions in human populations such as Crohn's disease.

Copyright $\odot 2009$ S. Karger AG, Basel
\end{abstract}

\section{Introduction}

The study of the immunological roles of autophagy has become a rapidly growing field taking on the role of a frontier in contemporary immunological research. Autophagy is the evolutionarily conserved, ubiquitous biological process of cleaning the eukaryotic cell's interior. During autophagy, large portions of the cytoplasm that can be as big as whole organelles (e.g. mitochondria) are captured by isolation membranes (phagophores) and sequestered into autophagosomes for degradation within the specialized lytic organelles termed autolysosomes [16]. The genes (Atg) involved in this pathway [7] have been identified in species from yeast to humans. Autophagy affects a wide range of immunological processes: (1) innate and adaptive immunity against intracellular pathogens, including bacteria (e.g. Mycobacterium tuberculosis), protozoa and viruses $[3,4,8-18$; see also Deretic V. (ed): Autophagy in Immunity and Infection: a Novel Immune Effector. Weinheim, Wiley-VCH, 2006]; (2) antigen presentation [18-21]; (3) homeostasis of immune cells [22-24], and (4) inflammatory disorders, such as Crohn's disease [25-29]. More broadly, autophagy affects cell death and survival, and is implicated in many human health and disease states such as cancer, aging and longevity [30-32]. We particularly stress the utility of autophagy as a cell-autonomous defense against intracellular pathogens. When induced, autophagy can eliminate notorious intracellular microbes $[8,9,33]$. In contrast to

\section{KARGER \\ Fax +4161306 1234 \\ E-Mail karger@karger.ch}

www.karger.com
(C) 2009 S. Karger AG, Basel

0257-2753/09/0273-0246\$26.00/0

Accessible online at:

www.karger.com/ddi
Vojo Deretic, $\mathrm{PhD}$

Department of Molecular Genetics and Microbiology

University of New Mexico Health Sciences Center

915 Camino de Salud, NE, Albuquerque, NM 87131-001 (USA)

Tel. +1 505272 0291, Fax +1 505272 5309, E-Mail vderetic@salud.unm.edu 
the notorious resistance of successful intracellular pathogens to a number of other microbicidal effectors, autophagy can efficiently eliminate intracellular microorganisms [8]. These observations have been confirmed by several groups in different contexts, including a report showing that autolysosomes contain ubiquitin fragments that act as mycobactericidal peptides [33], a study linking TLR stimulation and autophagy [34], a screen for novel autophagy inducers [35] and a recent study [36] showing that the previously reported ATP stimulation of P2X7 receptor leading to an elimination of intracellular mycobacteria [37] does so through autophagy [36]. Furthermore, a paper has just been published in Nature Medicine showing that autophagy induction can improve the vaccine potency of bacillus Calmette-Guérin (BCG) [38]. Only recently did mechanistic studies of autophagy become possible. The first book [Deretic V. (ed): Autophagosome and Phagosome. Totowa, Humana Press, 2008] that compiles autophagy methods has just recently been published [39]. The present toolbox for autophagy studies is limited by having very few pharmacological agonists and antagonists, boiling down to 2: rapamycin, an inducer, and 3-methyladenine, an inhibitor. However, rapamycin has been used clinically in the treatment of chronic conditions and transplantation and thus holds promise for application in Crohn's disease.

\section{Autophagy as a Mechanism for Cleaning up Cellular Interiors}

Autophagy impacts every cell in the human body and plays a role in a broad range of health and disease states. Autophagy is a fundamental cytoplasmic homeostasis process enabling individual cells to clean up, in a highly regulated fashion, their own cytoplasm by sequestering portions of the cytoplasm and degrading the captured constituents [1-6]. This primordial function is evolutionarily preserved in all eukaryotes, from yeast to human. The main morphological feature of autophagy is a membrane that wraps around portions of the cytoplasm earmarked to be sequestered, forming a double-membrane organelle termed autophagosome. The formation of autophagosomes is heralded by the appearance of punctate structures in the cytoplasm representing newly formed phagophores and autophagosomes. The captured material, once corralled into an autophagosome, is degraded upon autophagosomal fusion with lysosomal organelles. Autophagy has many physiological roles and is often employed to remove damaged or surplus organelles. It is also used by cells to turn over long-lived proteins and other macromolecules, either to get rid of protein aggregates or to supply nutrients for essential anabolic needs under conditions of nutrient deprivation or growth factor withdrawal. The broad spectrum of autophagy functions is hard-wired into a wide range of health-related issues, including cancer, neurodegeneration, aging and infections $[32,40]$. The most recent additions to the list of processes affected by autophagy are the control of intracellular pathogens $[8,10-12,15-17,40-42]$ and inflammatory conditions such as Crohn's disease [25-29].

\section{Autophagy in Immunity}

Autophagy plays a role in a wide spectrum of immunological processes $[40,43]$ with the list of immunological autophagy categories (dubbed 'immunophagy' $[3,4]$ ) rapidly growing [44].

(1) Autophagy in direct elimination of microbes: Autophagy is an innate immunity mechanism for the cellautonomous elimination of intracellular microbes $[8,10$ $12,15-17,40,42]$. In the context of infectious disease, autophagy - when induced by physiological (starvation), pharmacological (rapamycin) or immunological (IFN- $\gamma$ ) means - can eliminate a number of important intracellular pathogens, including prominently $M$. tuberculosis $[8,9,33]$. Attesting to the role of autophagy in eliminating microbes, many successful pathogens had to evolve ways to deal with or inhibit it $[17,45]$ as a part of their repertoire of anti-immune defenses.

(2) Autophagy as an effector of PRR/TLR signaling: Autophagy is an effector of TLR signaling [34, 46, 47], and can enhance or interfere with innate antiviral responses regulated by TLR7 [48] and RIG-I [49].

(3) Autophagy as an effector of Th1/Th2 polarization: Autophagy, in its role as an antimicrobial defense mechanism, is controlled by Th1/Th2 polarization [50]. The Th1 cytokines such as IFN- $\gamma[8,51]$, and TNF- $\alpha$ [52] also acting downstream of CD40 ligation [16], stimulate autophagy, whereas the Th2 cytokines IL-4 and IL-13 inhibit autophagy [50, 53-55].

(4) Autophagy in immune cell homeostasis: Autophagy controls $\mathrm{T}$ and $\mathrm{B}$ cell development, survival, and proliferation $[23,24,56]$.

(5) Autophagy, MHC II presentation and thymic selection: Autophagy contributes to MHC-II-restricted endogenous (cytosolic) antigen presentation $[18,19,57,58]$ with a role in thymic selection, allergy and autoimmune diseases [59]. 
(6) Autophagy and vaccines: Recent studies have shown that this newly discovered power of autophagy (MHC II presentation of cytoplasmic antigens) can be used for vaccine betterment as in the case of the influenza virus antigens $[19,60]$ and the widely used tuberculosis vaccine BCG [38].

(7) Autophagy in inflammation: Autophagy has recently been implicated in predisposition to Crohn's disease, a prevalent inflammatory bowel disease [61-63]. This latest breakthrough, made possible by the powerful genome-wide association screenings, has uncovered the role of autophagy in Crohn's disease, clearly demonstrating the role of autophagy in innate immunity in human populations [25-27, 29, 64], and a need to target this process for the treatment of a broad range of infectious and inflammatory diseases.

\section{Innate Immunity, Autophagy, ATG16L1 and IRGM in Crohn's Disease}

Genetic predisposition to Crohn's disease has been linked to regulators of innate immunity, of which Nod proteins (specifically Nod2) $[65,66]$ and most recently autophagy factors, including ATG16L1 and IRGM [25, 27, 67], are now some of the most prominent examples [26]. The specific role of Nod2 in Crohn's disease pathophysiology provides an obvious link with innate immunity and inflammation. Nod2 has been extensively studied and a considerable body of literature exists on this topic, including a very recent review [68]. The latest breakthroughs made possible by the powerful genome-wide association screenings have uncovered its role in at least 2 additional immunity pathways [26]: (1) IL-12 and IL-23 (IL23RArg381Gln) driving the Th17 differentiation of Th1 cells, with the Th17 phenotype often associated with organ-specific autoimmunity and inflammation, and (2) autophagy, a fundamental cellular homeostatic process involved in innate immunity against intracellular pathogens $[3,4,40]$ and in endogenous antigen presentation $[19,43]$.

In contrast to the extensively studied Nod2 pathway, almost nothing is known about the role of IRGM in Crohn's disease, due to the only very recent recognition of its linkage to Crohn's disease [25-27]. Interestingly, $I R G M$ is the only human gene representative of an otherwise prolific class of innate immunity effectors in vertebrates, called immunity-related GTPases (IRG) [69], also known as p47 GTPases [70]. In the mouse, there are 24 IRG genes and many of them have been initially recognized by their role in the defense against a variety of in- tracellular bacterial and protozoan pathogens. Intriguingly, humans and chimpanzees have only one IRG, IRGM [69], and now this gene has turned out to be a Crohn's disease predisposition locus [25-27].

Since the initial reports of an association of ATG16L1 and IRGM polymorphisms with Crohn's disease [25-29, 67], a growing number of replicating studies have confirmed this genetic link in general and in several specific populations [28, 71-79]. Although several risk loci are common to ulcerative colitis and Crohn's disease, the autophagy genes ATG16L1 and IRGM - along with NOD2 - appear to be specific to Crohn's disease [80] with some indications of the specificity of IRGM association with ileal disease in some populations [81]. A study including 2,731 Dutch and Belgian patients (1,656 with Crohn's disease and 1,075 with ulcerative colitis) and 1,086 controls showed association of ATG16L1 (rs2241880) and IRGM (rs4958847) specifically with Crohn's disease [79]. Single-nucleotide polymorphisms in the IRGM gene (rs1000113 and rs4958847) have confirmed that IRGM is a susceptibility locus specifically for Crohn's disease, either of adult or childhood onset, in Italian populations possibly being associated with fistulizing disease [79].

\section{Function of ATG16L1 and IRGM}

Functional information regarding the role of autophagy in humans in the context of Crohn's disease is still lacking. Some information has been gleaned from studies of ATG16L1 in vitro with cell lines or in vivo in mice, with the 3 published studies pointing to different, albeit potentially congruent, effects: (1) reduced capacity of the ATG16L1*300A allele to control intracellular enteric pathogens when examined in a human epithelial cell [82]; (2) susceptibility to dextran sulphate sodium-induced acute colitis in mice lacking Atg16L1 in hematopoietic cells and increase in IL-1 $\beta$ signaling with possible proinflammatory action [83], and (3) direct or indirect effects on Paneth cells in the intestinal crypts of ATG16L1-hypomorphic mice [84]. The role of IRGM cannot be properly investigated in mice, as the mouse has 24 IRGM-like genes, while humans have only 1 (IRGM); albeit 1, Irgm 1, of the 3 putative murine orthologs shows effects on hematopoietic stem cell proliferation and $\mathrm{T}$ cell survival $[85$, 86]. Some information on the direct function of the human IRGM in antibacterial defenses has been known even before autophagy loci have been linked with Crohn's disease [9]. Future work will be needed to establish the scope and extent of the role of autophagy in Crohn's disease. 


\section{Acknowledgement}

This work was supported by a Senior Research Award (CCFA 2053) 'Autophagy in Crohn's Disease' from the Crohn's and Colitis Foundation of America to V.D.

\section{Disclosure Statement}

The author declares that no financial or other conflict of interest exists in relation to the content of the article.

\section{References}

$>_{1}$ Shintani T, Klionsky DJ: Autophagy in health and disease: a double-edged sword. Science 2004;306:990-995.

2 Lum JJ, DeBerardinis RJ, Thompson CB: Autophagy in metazoans: cell survival in the land of plenty. Nat Rev Mol Cell Biol 2005;6: 439-448.

3 Deretic V: Autophagy in innate and adaptive immunity. Trends Immunol 2005;26:523528.

4 Deretic V, Levine B: Autophagy, immunity, and microbial adaptations. Cell Host Microbe 2009;5:527-549.

5 Levine B: Cell biology: autophagy and cancer. Nature 2007;446:745-747.

-6 Rubinsztein DC, Gestwicki JE, Murphy LO, Klionsky DJ: Potential therapeutic applications of autophagy. Nat Rev Drug Discov 2007;6:304-312.

7 Klionsky DJ, Cregg JM, Dunn WA Jr, Emr SD, Sakai Y, Sandoval IV, Sibirny A, Subramani S, Thumm M, Veenhuis M, Ohsumi Y: A unified nomenclature for yeast autophagyrelated genes. Dev Cell 2003;5:539-545.

8 Gutierrez MG, Master SS, Singh SB, Taylor GA, Colombo MI, Deretic V: Autophagy is a defense mechanism inhibiting BCG and $M y$ cobacterium tuberculosis survival in infected macrophages. Cell 2004;119:753-766.

9 Singh SB, Davis AS, Taylor GA, Deretic V: Human IRGM induces autophagy to eliminate intracellular mycobacteria. Science 2006;313:1438-1441.

10 Ogawa M, Yoshimori T, Suzuki T, Sagara H, Mizushima N, Sasakawa C: Escape of intracellular Shigella from autophagy. Science 2005;307:727-731.

-11 Nakagawa I, Amano A, Mizushima N, Yamamoto A, Yamaguchi H, Kamimoto T, Nara A, Funao J, Nakata M, Tsuda K, Hamada S, Yoshimori T: Autophagy defends cells against invading group A Streptococcus. Science 2004;306:1037-1040.

-12 Birmingham CL, Smith AC, Bakowski MA, Yoshimori T, Brumell JH: Autophagy controls Salmonella infection in response to damage to the Salmonella-containing vacuole. J Biol Chem 2006;281:11374-11383.

$\checkmark 13$ Liu Y, Schiff M, Czymmek K, Talloczy Z, Levine B, Dinesh-Kumar SP: Autophagy regulates programmed cell death during the plant innate immune response. Cell 2005; 121:567-577.
Checroun C, Wehrly TD, Fischer ER, Hayes SF, Celli J: Autophagy-mediated reentry of Francisella tularensis into the endocytic compartment after cytoplasmic replication. Proc Natl Acad Sci USA 2006;103:1457814583.

15 Ling YM, Shaw MH, Ayala C, Coppens I, Taylor GA, Ferguson DJ, Yap GS: Vacuolar and plasma membrane stripping and autophagic elimination of Toxoplasma gondii in primed effector macrophages. J Exp Med 2006;203:2063-2071.

-16 Andrade RM, Wessendarp M, Gubbels MJ, Striepen B, Subauste CS: CD40 induces macrophage anti-Toxoplasma gondii activity by triggering autophagy-dependent fusion of pathogen-containing vacuoles and lysosomes. J Clin Invest 2006;116:2366-2377.

17 Orvedahl A, Alexander D, Tallóczy Z, Sun Q, Wei Y, Zhang W, Burns D, Leib D, Levine B: HSV-1 ICP34.5 confers neurovirulence by targeting the Beclin 1 autophagy protein. Cell Host Microbe 2007;1:23-35.

- 18 Paludan C, Schmid D, Landthaler M, Vockerodt M, Kube D, Tuschl T, Münz C: Endogenous MHC class II processing of a viral nuclear antigen after autophagy. Science 2005; 307:593-596.

19 Schmid D, Pypaert M, Münz C: Antigenloading compartments for major histocompatibility complex class II molecules continuously receive input from autophagosomes. Immunity 2007;26:79-92.

20 Dengjel J, Schoor O, Fischer R, Reich M, Kraus M, Müller M, Kreymborg K, Altenberend F, Brandenburg J, Kalbacher H, Brock R, Driessen C, Rammensee HG, Stevanovic S: Autophagy promotes MHC class II presentation of peptides from intracellular source proteins. Proc Natl Acad Sci USA 2005; 102: 7922-7927.

21 Crotzer VL, Blum JS: Autophagy and intracellular surveillance: modulating MHC class II antigen presentation with stress. Proc Natl Acad Sci USA 2005;102:7779-7780.

22 Lum JJ, Bauer DE, Kong M, Harris MH, Li C, Lindsten T, Thompson CB: Growth factor regulation of autophagy and cell survival in the absence of apoptosis. Cell 2005;120:237248.

23 Pua HH, Dzhagalov I, Chuck M, Mizushima N, He YW: A critical role for the autophagy gene Atg 5 in T cell survival and proliferation. J Exp Med 2007;204:25-31.
24 Li C, Capan E, Zhao Y, Zhao J, Stolz D, Watkins SC, Jin S, Lu B: Autophagy is induced in CD4+ T cells and important for the growth factor-withdrawal cell death. J Immunol 2006;177:5163-5168.

25 Wellcome Trust Case Control Consortium: Genome-wide association study of 14,000 cases of seven common diseases and 3,000 shared controls. Nature 2007;447:661-678.

26 Massey D, Parkes M: Common pathways in Crohn's disease and other inflammatory diseases revealed by genomics. Gut 2007;56: 1489-1492.

27 Parkes M, Barrett JC, Prescott NJ, Tremelling M, Anderson CA, Fisher SA, Roberts RG, Nimmo ER, Cummings FR, Soars D, Drummond H, Lees CW, Khawaja SA, Bagnall R, Burke DA, Todhunter CE, Ahmad T, Onnie CM, McArdle W, Strachan D, Bethel G, Bryan C, Lewis CM, Deloukas P, Forbes A, Sanderson J, Jewell DP, Satsangi J, Mansfield JC, Cardon L, Mathew CG: Sequence variants in the autophagy gene IRGM and multiple other replicating loci contribute to Crohn's disease susceptibility. Nat Genet 2007;39:830-832.

28 Prescott NJ, Fisher SA, Franke A, Hampe J, Onnie CM, Soars D, Bagnall R, Mirza MM, Sanderson J, Forbes A, Mansfield JC, Lewis CM, Schreiber S, Mathew CG: A nonsynonymous SNP in ATG16L1 predisposes to ileal Crohn's disease and is independent of CARD15 and IBD5. Gastroenterology 2007; 132:1665-1671.

29 Rioux JD, Xavier RJ, Taylor KD, Silverberg MS, Goyette P, Huett A, Green T, Kuballa P, Barmada MM, Datta LW, Shugart YY, Griffiths AM, Targan SR, Ippoliti AF, Bernard EJ, Mei L, Nicolae DL, Regueiro M, Schumm LP, Steinhart AH, Rotter JI, Duerr RH, Cho JH, Daly MJ, Brant SR: Genomewide association study identifies new susceptibility loci for Crohn disease and implicates autophagy in disease pathogenesis. Nat Genet 2007;39:596-604.

30 Deretic V, Klionsky DJ: How cells clean house. Sci Am 2008;298:74-81.

31 Klionsky DJ: Autophagy: from phenomenology to molecular understanding in less than a decade. Nat Rev Mol Cell Biol 2007;8:931937.

32 Levine B, Kroemer G: Autophagy in the pathogenesis of disease. Cell 2008;132:2742 . 
-33 Alonso S, Pethe K, Russell DG, Purdy GE: Lysosomal killing of Mycobacterium mediated by ubiquitin-derived peptides is enhanced by autophagy. Proc Natl Acad Sci USA 2007;104:6031-6036.

- 34 Xu Y, Jagannath C, Liu XD, Sharafkhaneh A, Kolodziejska KE, Eissa NT: Toll-like receptor 4 is a sensor for autophagy associated with innate immunity. Immunity 2007;27: 135-144.

- 35 Floto RA, Sarkar S, Perlstein EO, Kampmann B, Schreiber SL, Rubinsztein DC: Small molecule enhancers of rapamycin-induced TOR inhibition promote autophagy, reduce toxicity in Huntington's disease models and enhance killing of mycobacteria by macrophages. Autophagy 2007;3:620-622.

- 36 Biswas D, Qureshi OS, Lee WY, Croudace JE, Mura M, Lammas DA: ATP-induced autophagy is associated with rapid killing of intracellular mycobacteria within human monocytes/macrophages. BMC Immunol 2008;9: 35.

-37 Lammas DA, Stober C, Harvey CJ, Kendrick N, Panchalingam S, Kumararatne DS: ATPinduced killing of mycobacteria by human macrophages is mediated by purinergic $\mathrm{P} 2 \mathrm{Z}$ (P2X7) receptors. Immunity 1997;7:433444.

38 Jagannath C, Lindsey DR, Dhandayuthapani S, Xu Y, Hunter RL Jr, Eissa NT: Autophagy enhances the efficacy of BCG vaccine by increasing peptide presentation in mouse dendritic cells. Nat Med 2009;15:267-276.

-39 Deretic V, Klionsky DJ: How cells clean house. Sci Am 2008;298:74-81.

$\checkmark 40$ Levine B, Deretic V: Unveiling the roles of autophagy in innate and adaptive immunity. Nat Rev Immunol 2007;7:767-777.

-41 Py BF, Lipinski MM, Yuan J: Autophagy limits Listeria monocytogenes intracellular growth in the early phase of primary infection. Autophagy 2007;3:117-125.

-42 Birmingham CL, Canadien V, Kaniuk NA, Steinberg BE, Higgins DE, Brumell JH: Listeriolysin $\mathrm{O}$ allows Listeria monocytogenes replication in macrophage vacuoles. Nature 2008;451:350-354.

43 Schmid D, Münz C: Innate and adaptive immunity through autophagy. Immunity 2007; 27:11-21.

44 Deretic V, Master S, Singh S: Autophagy gives a nod and a wink to the inflammasome and Paneth cells in Crohn's disease. Dev Cell 2008;15:641-642.

\45 Gutierrez MG, Vazquez CL, Munafo DB, Zoppino FC, Beron W, Rabinovitch M, Colombo MI: Autophagy induction favours the generation and maturation of the Coxiellareplicative vacuoles. Cell Microbiol 2005;7: 981-993.

-46 Sanjuan MA, Dillon CP, Tait SW, Moshiach S, Dorsey F, Connell S, Komatsu M, Tanaka K, Cleveland JL, Withoff S, Green DR: Tolllike receptor signalling in macrophages links the autophagy pathway to phagocytosis. Nature 2007;450:1253-1257.
47 Delgado MA, Elmaoued RA, Davis AS, Kyei G, Deretic V: Toll-like receptors control autophagy. EMBO J 2008;27:1110-1121.

48 Lee HK, Lund JM, Ramanathan B, Mizushima N, Iwasaki A: Autophagy-dependent viral recognition by plasmacytoid dendritic cells. Science 2007;315:1398-1401.

49 Jounai N, Takeshita F, Kobiyama K, Sawano A, Miyawaki A, Xin KQ, Ishii KJ, Kawai T, Akira S, Suzuki K, Okuda K: The Atg5 Atg12 conjugate associates with innate antiviral immune responses. Proc Natl Acad Sci USA 2007;104:14050-14055.

50 Harris J, de Haro SA, Master SS, Keane J, Roberts EA, Delgado M, Deretic V: T helper 2 cytokines inhibit autophagic control of intracellular Mycobacterium tuberculosis. Immunity 2007;27:505-517.

51 Inbal B, Bialik S, Sabanay I, Shani G, Kimchi A: DAP kinase and DRP-1 mediate membrane blebbing and the formation of autophagic vesicles during programmed cell death. J Cell Biol 2002;157:455-468.

52 Djavaheri-Mergny M, Amelotti M, Mathieu J, Besancon F, Bauvy C, Souquere S, Pierron G, Codogno P: NF-кB activation represses tumor necrosis factor- $\alpha$-induced autophagy. J Biol Chem 2006;281:30373-30382.

-53 Arico S, Petiot A, Bauvy C, Dubbelhuis PF, Meijer AJ, Codogno P, Ogier-Denis E: The tumor suppressor PTEN positively regulates macroautophagy by inhibiting the phosphatidylinositol 3-kinase/protein kinase B pathway. J Biol Chem 2001;276:35243-35246.

54 Petiot A, Ogier-Denis E, Blommaart EF, Meijer AJ, Codogno P: Distinct classes of phosphatidylinositol 3-kinases are involved in signaling pathways that control macroautophagy in HT-29 cells. J Biol Chem 2000; 275:992-998.

55 Scarlatti F, Bauvy C, Ventruti A, Sala G, Cluzeaud F, Vandewalle A, Ghidoni R, Codogno P: Ceramide-mediated macroautophagy involves inhibition of protein kinase $\mathrm{B}$ and up-regulation of beclin 1. J Biol Chem 2004; 279:18384-18391.

56 Miller BC, Zhao Z, Stephenson LM, Cadwell K, Pua HH, Lee HK, Mizushima NN, Iwasaki A, He YW, Swat W, Virgin HW 4th: The autophagy gene ATG5 plays an essential role in B lymphocyte development. Autophagy 2008;4:309-314.

57 Dörfel D, Appel S, Grünebach F, Weck MM, Müller MR, Heine A, Brossart P: Processing and presentation of HLA class I and II epitopes by dendritic cells after transfection with in vitro-transcribed MUC1 RNA. Blood 2005;105:3199-3205.

58 Dengjel J, Schoor O, Fischer R, Reich M, Kraus M, Müller M, Kreymborg K, Altenberend F, Brandenburg J, Kalbacher H, Brock R, Driessen C, Rammensee HG, Stevanovic S: Autophagy promotes MHC class II presentation of peptides from intracellular source proteins. Proc Natl Acad Sci USA 2005; 102: 7922-7927.
59 Nedjic J, Aichinger M, Emmerich J, Mizushima N, Klein L: Autophagy in thymic epithelium shapes the T-cell repertoire and is essential for tolerance. Nature 2008;455: 396-400.

60 Münz C: Enhancing immunity through autophagy. Annu Rev Immunol 2009;27:423449.

61 Crohn BB, Ginzburg L, Oppenheimer GD: Regional ileitis: a pathologic and clinical entity (1932). Mt Sinai J Med 2000;67:263268

62 Hanauer SB: Inflammatory bowel disease. N Engl J Med 1996;334:841-848.

63 Podolsky DK: Inflammatory bowel disease. N Engl J Med 2002;347:417-429.

64 Hampe J, Franke A, Rosenstiel P, Till A, Teuber M, Huse K, Albrecht M, Mayr G, de la Vega FM, Briggs J, Günther S, Prescott NJ, Onnie CM, Häsler R, Sipos B, Fölsch UR, Lengauer T, Platzer M, Mathew CG, Krawczak M, Schreiber S: A genome-wide association scan of nonsynonymous SNPs identifies a susceptibility variant for Crohn disease in ATG16L1. Nat Genet 2007;39:207-211.

65 Ogura Y, Bonen DK, Inohara N, Nicolae DL, Chen FF, Ramos R, Britton H, Moran T, Karaliuskas R, Duerr RH, Achkar JP, Brant SR, Bayless TM, Kirschner BS, Hanauer SB, Nunez G, Cho JH: A frameshift mutation in NOD2 associated with susceptibility to Crohn's disease. Nature 2001;411:603-606.

-66 Hugot JP, Chamaillard M, Zouali H, Lesage S, Cezard JP, Belaiche J, Almer S, Tysk C, O’Morain CA, Gassull M, Binder V, Finkel Y, Cortot A, Modigliani R, Laurent-Puig P, Gower-Rousseau C, Macry J, Colombel JF, Sahbatou M, Thomas G: Association of NOD2 leucine-rich repeat variants with susceptibility to Crohn's disease. Nature 2001; 411:599-603.

67 McCarroll SA, Huett A, Kuballa P, Chilewski SD, Landry A, Goyette P, Zody MC, Hall JL, Brant SR, Cho JH, Duerr RH, Silverberg MS, Taylor KD, Rioux JD, Altshuler D, Daly MJ, Xavier RJ: Deletion polymorphism upstream of IRGM associated with altered IRGM expression and Crohn's disease. Nat Genet 2008;40:1107-1112.

68 Kanneganti TD, Lamkanfi M, Nunez G: Intracellular NOD-like receptors in host defense and disease. Immunity 2007;27:549559.

69 Bekpen C, Marques-Bonet T, Alkan C, Antonacci F, Leogrande MB, Ventura M, Kidd JM, Siswara P, Howard JC, Eichler EE: Death and resurrection of the human IRGM gene. PLoS Genet 2009;5:e1000403.

70 Taylor GA, Feng CG, Sher A: p47 GTPases: regulators of immunity to intracellular pathogens. Nat Rev Immunol 2004;4:100109. 
-71 Baldassano RN, Bradfield JP, Monos DS, Kim CE, Glessner JT, Casalunovo T, Frackelton EC, Otieno FG, Kanterakis S, Shaner JL, Smith RM, Eckert AW, Robinson LJ, Onyiah CC, Abrams DJ, Chiavacci RM, Skraban R, Devoto M, Grant SF, Hakonarson H: Association of the T300A non-synonymous variant of the ATG16L1 gene with susceptibility to paediatric Crohn's disease. Gut 2007;56: 1171-1173.

-72 Cummings JR, Cooney R, Pathan S, Anderson CA, Barrett JC, Beckly J, Geremia A, Hancock L, Guo C, Ahmad T, Cardon LR, Jewell DP: Confirmation of the role of ATG16L1 as a Crohn's disease susceptibility gene. Inflamm Bowel Dis 2007;13:941-946.

73 Roberts RL, Gearry RB, Hollis-Moffatt JE, Miller AL, Reid J, Abkevich V, Timms KM, Gutin A, Lanchbury JS, Merriman TR, Barclay ML, Kennedy MA: IL23R R381Q and ATG16L1 T300A are strongly associated with Crohn's disease in a study of New Zealand Caucasians with inflammatory bowel disease. Am J Gastroenterol 2007;102:27542761.

-74 Fowler EV, Doecke J, Simms LA, Zhao ZZ, Webb PM, Hayward NK, Whiteman DC, Florin TH, Montgomery GW, Cavanaugh JA, Radford-Smith GL: ATG16L1 T300A shows strong associations with disease subgroups in a large Australian IBD population: further support for significant disease heterogeneity. Am J Gastroenterol 2008;103: 2519-2526.

-75 Glas J, Konrad A, Schmechel S, Dambacher J, Seiderer J, Schroff F, Wetzke M, Roeske D, Török HP, Tonenchi L, Pfennig S, Haller D, Griga T, Klein W, Epplen JT, Folwaczny C, Lohse P, Göke B, Ochsenkühn T, Mussack T, Folwaczny M, Müller-Myhsok B, Brand S: The ATG16L1 gene variants rs2241879 and rs2241880 (T300A) are strongly associated with susceptibility to Crohn's disease in the German population. Am J Gastroenterol 2008;103:682-691.
6 Okazaki T, Wang MH, Rawsthorne P, Sargent M, Datta LW, Shugart YY, Bernstein CN, Brant SR: Contributions of IBD5, IL23R, ATG16L1, and NOD2 to Crohn's disease risk in a population-based case-control study: evidence of gene-gene interactions. Inflamm Bowel Dis 2008;14:1528-1541.

77 Weersma RK, Zhernakova A, Nolte IM, Lefebvre C, Rioux JD, Mulder F, van Dullemen HM, Kleibeuker JH, Wijmenga C, Dijkstra G: ATG16L1 and IL23R are associated with inflammatory bowel diseases but not with celiac disease in the Netherlands. Am J Gastroenterol 2008;103:621-627.

-78 van Limbergen J, Russell RK, Nimmo ER, Drummond HE, Smith L, Anderson NH, Davies G, Gillett PM, McGrogan P, Weaver LT, Bisset LW, Mahdi G, Arnott ID, Wilson DC, Satsangi J: Autophagy gene ATG16L1 influences susceptibility and disease location but not childhood-onset in Crohn's disease in Northern Europe. Inflamm Bowel Dis 2008; 14:338-346.

79 Latiano A, Palmieri O, Cucchiara S, Castro M, D’Inca R, Guariso G, Dallapiccola B, Valvano MR, Latiano T, Andriulli A, Annese V: Polymorphism of the IRGM gene might predispose to fistulizing behavior in Crohn's disease. Am J Gastroenterol 2009;104:110116.

80 Fisher SA, Tremelling M, Anderson CA, Gwilliam R, Bumpstead S, Prescott NJ, Nimmo ER, Massey D, Berzuini C, Johnson C, Barrett JC, Cummings FR, Drummond $\mathrm{H}$, Lees CW, Onnie CM, Hanson CE, Blaszczyk $\mathrm{K}$, Inouye M, Ewels P, Ravindrarajah R, Keniry A, Hunt S, Carter M, Watkins N, Ouwehand W, Lewis CM, Cardon L, Lobo A, Forbes A, Sanderson J, Jewell DP, Mansfield JC, Deloukas P, Mathew CG, Parkes M, Satsangi J: Genetic determinants of ulcerative colitis include the ECM1 locus and five loci implicated in Crohn's disease. Nat Genet 2008;40:710-712.
81 Roberts RL, Hollis-Moffatt JE, Gearry RB, Kennedy MA, Barclay ML, Merriman TR: Confirmation of association of IRGM and NCF4 with ileal Crohn's disease in a population-based cohort. Genes Immun 2008;9: 561-565.

82 Kuballa P, Huett A, Rioux JD, Daly MJ, Xavier RJ: Impaired autophagy of an intracellular pathogen induced by a Crohn's disease associated ATG16L1 variant. PLoS One 2008;3:e3391.

83 Saitoh T, Fujita N, Jang MH, Uematsu S, Yang BG, Satoh T, Omori H, Noda T, Yamamoto N, Komatsu M, Tanaka K, Kawai T, Tsujimura T, Takeuchi O, Yoshimori T, Akira S: Loss of the autophagy protein Atg16L1 enhances endotoxin-induced IL-1 $\beta$ production. Nature 2008;456:264-268.

-84 Cadwell K, Liu JY, Brown SL, Miyoshi H, Loh J, Lennerz JK, Kishi C, Kc W, Carrero JA, Hunt S, Stone CD, Brunt EM, Xavier RJ, Sleckman BP, Li E, Mizushima N, Stappenbeck TS, Virgin HW 4th: A key role for autophagy and the autophagy gene Atg16l1 in mouse and human intestinal Paneth cells. Nature 2008;456:259-263.

- 85 Feng CG, Weksberg DC, Taylor GA, Sher A Goodell MA: The p47 GTPase Lrg-47 (Irgm1) links host defense and hematopoietic stem cell proliferation. Cell Stem Cell 2008;2:8389.

86 Feng CG, Zheng L, Jankovic D, Bafica A, Cannons JL, Watford WT, Chaussabel D, Hieny S, Caspar P, Schwartzberg PL, Lenardo MJ, Sher A: The immunity-related GTPase $\operatorname{Irgm} 1$ promotes the expansion of activated $\mathrm{CD} 4+\mathrm{T}$ cell populations by preventing interferon- $\boldsymbol{\gamma}$-induced cell death. Nat Immunol 2008;9:1279-1287. 